\title{
Leadership And Strengthening Work Program And Extracurricular Development Of Hizbul Wathan As Effort To Achieve Quality Education In Islamic Education Institutions
}

\author{
(Case Study of SMA Muhammadiyah 25 Pamulang, Banten, Indonesia) \\ Margono', Sularno $^{2}$ \\ ${ }^{1}$ Margono Mitrohardjono, Dosen Program Doktor, MPI, Universitas Muhamadiyah Jakarta \\ ${ }^{2}$ Sularno, Program Doktor S3, MPI, Universitas Muhammadiyah, Jakarta \\ DOI: 10.29322/IJSRP.11.08.2021.p11634 \\ http://dx.doi.org/10.29322/IJSRP.11.08.2021.p11634
}

\begin{abstract}
The purpose of this study is to identify proactive and innovative leadership and implement a comprehensive work program accompanied by strengthening character education through extracurricular coaching "Hizbul Wathan (HW)" as a nonacademic activity, to realize the quality of education, at the the SMA-M25, Banten. The main data collection by interview, is also equipped with observation and documentation. The results of the study indicate that the ability or so-called competence increases by strengthening the knowledge, physical and mental of students, where are the SMA-M25, Banten, have the foundation and qualifications of intelligent, skilled and strong character in the nation and state as a Muslim, establish Ukhuwah Islamiyah (islamic brotherhood) and Wathaniyah (compatriots), as well as mutual cooperation and mutual respect among each other in maintaining the integrity of the Indonesian nation. The success of graduates from SMA-M25, Banten, improved the quality of education, have a moral personality and have the skills of "life and career skills" in order to live independently.
\end{abstract}

Index Terms- Character Education, Quality Education, Strategic Leadership, Success, Work Program.

\section{INTRODUCTION}

$\mathrm{W}$ ith the implementation of the zoning system in the management of education in Indonesia, educational institutions are required to be able to compete in order to become a superior school and become the choice of students, including parents of students. This is inseparable from Islamic educational institutions, including education within Muhammadiyah. Educational institutions do not only sell Vision, Mission and Programs and also include academic achievements, but must also be able to realize non-academic achievements, which measure the success of outputs and outcomes, overall with the term quality education with excellent student competence. Student competencies consist of core competencies and basic competencies, and if realized include; These include: 1. Knowledge, namely the ability in the cognitive field, 2. Understanding, namely the depth of knowledge possessed by each individual, 3.Skills, 4.Values (values), namely the norms to implement in practice. about the tasks assigned to him,

5. Attitude, namely the individual's view of something,

6. Interest, namely the individual's tendency to do an act (Holis, Gus. 2013. Curriculum 2013)

Leadership (leadership) with regard to someone influencing the behavior of others for a purpose. With power, leaders can influence the behavior of their subordinates (Yudiatmaja, 2018), Leadership in education is the ability to move all personnel of an education unit or school in carrying out learning tasks in accordance with pedagogical principles (Haryanto, 2019). Leadership and work programs summarized in strategic management are two inseparable things. Strategic management requires a leadership figure who is able to improve the quality of Islamic education. Leadership which is one of the management functions is very important to achieve organizational goals. (Thaib, 2018) The concept of leadership itself in the perspective of Islamic teachings has a strong foundation in the Al-Quran and Hadith. The arguments of the Qur'an are very clear about the issue of leadership as implied in the Qur'an surah al- Baqarah verse 30: (QS: Al Baqarah; 2/30) 
International Journal of Scientific and Research Publications, Volume 11, Issue 8, August 2021

247

ISSN 2250-3153

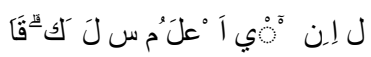

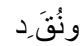

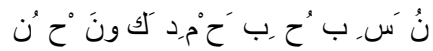

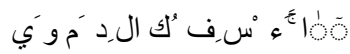

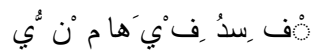

مَيَ هـا

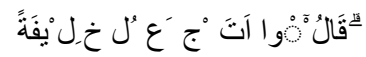

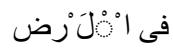

جا -ع إل

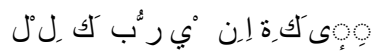

"And (remember) when your Lord said to the angels, "I want to make a caliph on earth." They said, "Are you going to make people who destroy and shed blood there, while we glorify You and sanctify Your name?" He said, "Truly, I know what you do not know." 
Likewise, it is mentioned in the hadith of the Prophet Muhammad which alludes to the role of a leader towards those who are led. Sahih Hadith narrated by al-Bukhari: 4789;

"Each of you is a leader, and each of you will be held accountable. An imam is a leader and will be held accountable. A man is the leader of his family and he will be held accountable. A woman is the leader of her husband's house, and she will be held accountable. A slave is also a leader over his master's property and he will also be held accountable. Indeed, each of you is a leader and each of you will be held accountable." Work programs, in general, its put in

School Strategic Management (SSM), and in SSM, there are two meanings in a broad and narrow sense. SSM in a narrow sense is a school/madrasah management, mainly about; principal leadership which includes: school/madrasah's program planning, program implementation schools/madrasahs, principals/madrasah leadership, supervisors/evaluations, and school/madrasah information systems (Budio,2019). In a broad management, all components of education must always be oriented towards achieving quality, all educational and learning programs and activities in educational institutions must essentially be directed at achieving quality (Qomar, 2017). Schools as one of the centers for implementing educational activities are structured institutions that have a role in improving the quality of education (Irani, 2019).

Quality of Education according to Husaini Usman (in (Ryanta, 2016) is conformity to market needs, how far a product has met the requirements that have been set. Outcomes are declared quality if graduates are absorbed in the world of work. According to Umar and Ismail (2017), In fact, problematic The problems faced by Islamic educational institutions are so diverse, ranging from management problems, leadership problems, human resources, finance, and institutional problems. Efforts to improve the quality of education are issues that will continue to be discussed in education management/management. organization is absolutely necessary as well, in management education is an important thing. In the Koran is reminded by Allah through His word, in the letter al-Hasyr: (Surat al- Hasyr: 59/18).

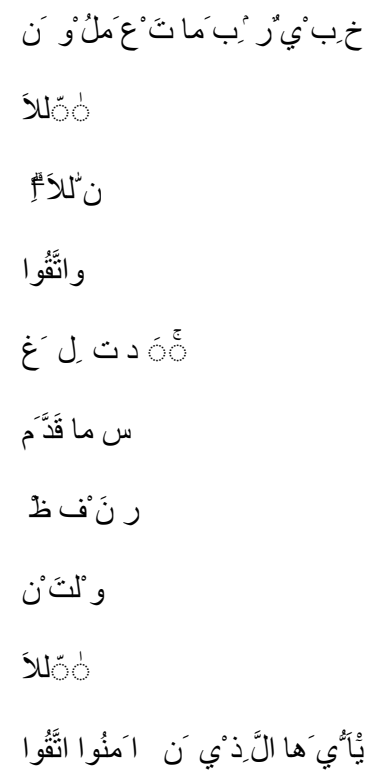

"O you who believe! Fear Allah and let everyone pay attention to what he has done for tomorrow (the hereafter), and fear Allah. Indeed, Allah is All-Aware of what you do" 
At Muhammadiyah Senior High School no. 25, Pamulang, Banten (SMA-M25, Banten). attempts to develop and strive to become a school that can achieve quality education. SMA-M25, Banten implements strategic management and character education through Hizbul Wathan guided activities which are expected to be able to display high performance and achievements, in accordance with organizational goals. Hizbul Wathan (HW) is the designation of Scouting in Muhammadiyah, HW means "Defender of the Fatherland". HW is one of the autonomous organizations in Muhammadiyah for both men and women. The HW organization is used as an extracurricular activity in all Muhammadiyah schools, starting from the elementary school level to the university level. HW's scouting activities are non- formal coaching, carried out in the family environment and in the educational environment, as an autonomous organization from Muhammadiyah. (HW Jaya Melati Scout Movement 1 HW Central Quarter 2017, p.20). The activities of this organization have many benefits, apart from the Muhammadiyah da'wah (invitation or appeal) facility, this organization is also one of the methods of education and discipline development in Muhammadiyah schools. It is hoped that self- discipline will strengthen the character of students as well as have the spirit of defending the country, so that student achievement can be realized which can lead to the realization of quality education.

\section{RESEARCH ELABORATIONS AND COLLECT DATA}

\section{Literature Review}

1. Journal; By Rosi Rosita, School Principal's Efforts in Improving the Quality of Islamic Education TARBAW, Vol. 3, Number 1, (2016), The results show that: 1) MTs Al-Inayah Bandung has experienced a good quality improvement. Under the leadership of a reliable principal, MTs Al-Inayah Bandung can now become one of the Islamic educational institutions that are at the forefront and are able to produce outstanding output. 2) The principal's efforts in improving the quality of education, namely:

a) increasing the professionalism of teachers by creating rules for teachers, placing teachers according to their abilities, giving confidence and motivation, and conducting coaching. b) improving the quality of infrastructure through improving infrastructure, cooperating with other institutions/agencies in the procurement of infrastructure. c) improve the quality of the learning process by developing Islamic education models, improving learning methods, managing curriculum quality. d) improve student achievement by holding strengthening activities, additional lessons, collaboration with tutoring institutions, guiding teachers to create effective learning, creating a disciplined school culture, providing various extracurricular, sending students in various competitions.

2. Journal; By Aldo Redho Syam, The Concept of Quality Leadership in Islamic Education, At-Ta'dib. Vol. 12. No. 2, December 2017. Leaders in Islamic educational institutions have a great responsibility, because of their role such as the ability to make decisions and skills in making new ideas as the demands of society. Being a leader in Islamic educational institution is not only required to master various leadership theories, but also must be able to apply them in the institution. Some principles that must be owned by a leader in carrying out his leadership in an Islamic educational institution should rely on things that have been ordered by Allah SWT. Principles of leadership in Islam namely trust, fair, deliberation, and amar ma'ruf nahi munkar. While qualifications of leader in Islamic education as follows: sincere, always take the initiative, able to create network and use it, trustworthy, work hard and earnest, mastering the problem and can solve it, have high integrity, have high guts and not afraid of risk, honest and open, ready to sacrifice, assertive, intelligent in seeing, listening, evaluating, judging, deciding, and solving it, able to communicate, and Good in mu'amalah.

3. Journal; Strategies for Effective School Leadership, April 2015, Global Journal of Educational Studies ISSN 2377-3936 2015, Vol. 1, No. 1, By John Nikolaros ; To many, effective leadership is continently appropriate as conscience. The paper identifies strategies that assists schools facilitate a warmer and healthier school environment. The author provides a review of delineated leadership strategies with a narrative for each type. Highlighting different cultures and assumptive impact on school culture and climate is offered.

4. Journal; Mualiimuna Vol. 2, No. 1, October, 2016, The Role of the Scout Movement to form the Character of Social Concern and Independence (Case Study at SDIT Ukhwah and MIS An-Nuriyyah 2 Banjarmasin) by; Sa'adah Erliani Lecturer of STKIP PGRI Banjarmasin. The results of the supporting tools include the basic principles of scouting, scouting methods, and a code of honor. The character formation in the Scout movement MIS An-Nuriyah 2 Banjarmasin is exemplary habituation, success, and achievements as well as reprimands and awards. The tools include the basic principles of scouting, scouting methods and a code of honor.

\section{Research Methods}

This research uses qualitative research methods. To overcome these problems, certain and methods are used according to the topic being 
discussed. This method was chosen so that research can provide positive data and believe in the truth. To get an overview of qualitative research, there are several main characteristics of this research, namely: Based on the conditions of the research place, conducting a study of research that has been carried out based on actual data, and open research. The research was conducted at SMA-M25, Banten, by conducting interviews and observations on leaders, teachers and students. The results were discussed with experts for data validation at the Forum Groups Discussions.

\section{RESULTS / FINDING AND DISCUSSION}

SMA-M25, Banten; address at Setiabudi Pamullang, J1. Surya Kencana No. 29 Pamulang- Tangerang Selatan, Banten Indonesia, works hard to create a quality school, and students who excel. From the results of interviews obtained data from SMA Muhammadiyah 25 Pamulang, Banten, as follows 1.Vision and Mission of SMA-M25, Banten

Vision and Mission of SMA-M25, Banten, has a vision to realize international standard academic and non-academic achievements, promote religious values, customs and based on faith and piety. And the mission (1) is to encourage students to compete honestly and athletically in academic and non- academic fields for the best results. (2) Optimizing students' abilities to reach their potential. (3) Promotion and development of students' talents and interests. (4) Improvement of Information and Communication Technology (ICT) Program to improve student achievement. (5) Improving the English language skills of students, educators and education staff. In realizing this vision and mission, the hard work of school residents works hand in hand and complements each other, by continuing to make corrections if there are deficiencies that cannot be fulfilled. From the Strategic Plan (Renstra) that was launched for 10 years, from 2020 to 2025, it continues to be developed with control carried out by being included in the annual Operational Plan (Renop) so that work programs can be carried out with full attention and well controlled. Likewise, by inviting parents who go through the School Committee to be invited to dialogue so that they are seriously willing to participate in advancing the school.

The role of the leadership and members of the Muhammadiyah organization is actually very supportive and supportive of the programs launched by the school, so that in addition to facilitating the program implementation process, it also brings an opymiste atmosphere to the Muhammadiyah 25 Senior High School.

\section{SWOT Analysis Results}

The leadership strategy that will be applied in implementing the program to achieve the stated goals is the Islamic education leadership strategy. is a strategy based on the following sources: a. Al-Qur'an Al-karim, b. Sunnah of the Prophet (Exemplary leadership of the household, social / community, and the state of Medina), c. Al-Qawiyy (competence), d.Shidiq (honesty), e.Amanah (trustworthy, true, and fair), f.Tabligh (communication and openness), g.Fathanah (intelligent and cunning, tactical, strategic), and others.

The main programs that will be planned to realize high-quality madrasas include: a. Champion School Principal Program; This program aims to realize the leadership of school principals who are professional, creative and innovative. This program is in the form of the principal's participation in participating in every workshop or training involving principals' participants both in improving the competence of principals and competitions between principals, b. Understand and Introduce School Program; This program aims to instill an understanding of all school apparatus about the Vision, Mission, and Objectives and Programs of the school so that all school apparatus make it the basis for carrying out their respective duties. In addition, it is also a strategy for school promotion media through the role of school officials. c. Love the School Environment Program; This program aims to instill a sense of love for all school staff for the school environment through a cultural program to maintain school cleanliness so that a healthy, safe, and comfortable learning environment can be realized. d. My Home Science Program; This program aims to create a learning process that is enjoyable for all parties, especially for students and teachers as well as the realization of effective and goal-focused learning.

e. Champion Student Program; This program aims to produce high student learning outcomes, both academically and nonacademically so that later it can become the capital for students when they graduate to be able to continue to their favorite high school. This program is supported by the presence of extra- curricular programs for students by presenting competent, highachieving, and quality extracurricular trainers, and other programs.

\section{The role of leadership in implementing work programs (As the School's Strategic Management)}

The role of leadership in an Islamic education institution has a central role, because only a leader who has ideal characteristics is able to influence changes in the policy direction of an Islamic education. Islamic teachings also require ideal leadership characteristics such as trustworthiness, honesty, and fairness, but also have strategic steps based on the vision and mission of the future to face global challenges in the industrial era 4.0. For this reason, strategic leadership can have an influence on improving the quality of Islamic education through the implementation of correct and targeted strategic management in accordance with the quality standards of Islamic education. 
International Journal of Scientific and Research Publications, Volume 11, Issue 8, August 2021

251

ISSN 2250-3153

2.1. Efforts are made for the school's vision to support student learning. The comprehensive school programming process provides a symbiosis between curriculum, teaching, assessment, and implementation must be poly (various) existence in a successful school environment.

2.2. Focus on student achievement is a predictor of school proximity and regulation. This focus on improving student achievement is a central, legal proposition (professionally) for school leadership. Accurate evaluation of student skills including student performance on various types of assessments is carried out. Efforts are made to improve student outcomes on state standard testing (accreditation).

2.3. Efforts are being made to continue to improve the quality of schools so that they can exceed the targets that have been targeted.

2.4. Principals consult with teachers and the community based on togetherness which can influence schools to build interdependence among stakeholders. Reward or instill respect for contributing to the school.

2.5 Evaluation of Methods that are inconsistent in activities, rules, strategies, and implementation can mark the parameters of sustainability and success 4. Work Program Matrix

This SMA M25, Banten work program is a continuation or detail of the results of the SWOT analysis which was approved by both the Muhammadiyah SMA leaders, as well as the PP Muhammadiyah Education Supervisor and Supervisor.

4.1. Work Program SMA M25, Banten (The matrix detail program bellow)

4.1.1. Short-term work program for the 2020/2021 study year; This short-term program is general in nature covering several fields, including: 1. Learninf and Curriculum, 2. Student Development (Affairs), 3. Public Relations, 4. Facilities and Infrastructure, 5. Organization and management. 4.1.2.Student Development 4.1.2. Medium-Long term program for academic year 2020/2021 to 2025/2026, For 5 years. And 4.1.3. Quality Improvement Program in SMA M 255 Banten

\subsection{School Objectives}

The school's objectives are: (1) to foster students in strengthening intelligence, creativity, interest abilities, and personality according to Islamic teachings. (2) Advancing students' abilities for the best results in school. (3) The encouragement and needs of students can achieve perfect results at the level of ability in schools. (4) create high achieving students and quality schools

\section{Matrix of 4.1.1. Short-term work program for the 2020/2021 study year}

\begin{tabular}{|c|c|c|c|c|}
\hline NO. & FIELD & $\begin{array}{l}\text { MISSION } \\
\text { DESCRIPTION }\end{array}$ & PROGRAM OPERATING PLAN & TARGET \\
\hline 1 & $\begin{array}{l}\text { 1.1.Learning } \\
\text { and } \\
\text { Curriculum }\end{array}$ & $\begin{array}{l}\text { 1.1.1. Provide } \\
\text { excellent } \\
\text { curriculum } \\
\text { services with a } \\
\text { quality and } \\
\text { primery } \\
\text { curriculum }\end{array}$ & $\begin{array}{l}\text { 1.Understanding and Exploration the } \\
\text { National Curriculum K-13, in order to } \\
\text { prepare for the National (UN) and } \\
\text { Examination, 2. Analyze the test to } \\
\text { determine the level of difficulty of the } \\
\text { questions.3. Academic Aptitude test for } \\
\text { National Science Olympiad (OSN) team } \\
\text { recruitment, 4. Learning OSN Materials for } \\
\text { selected students, 5. Organizing In House } \\
\text { Training (IHT) for teachers for Qulity and } \\
\text { primery curriculum. 6. Conducting / } \\
\text { practice do to improve exam score 7. } \\
\text { Workshops/seminars in the context of } \\
\text { using the internet and the " Sipintar " } \\
\text { application in learning and assessment }\end{array}$ & $\begin{array}{l}\text { 1.Apply National Curriculum K-13. } \\
\text { Increasing the results of the UN. } \\
\text { 2.Increasing value OUTPUT and } \\
\text { OUTCOME, 3.Improved school ranking for } \\
\text { the National Examination (minimum of } 6 \\
\text { provinces) 4.Selection as representatives } \\
\text { for OSN as much 5.Increasing the number } \\
\text { of students accepted by PTN through the } \\
\text { invitation, independent and written } \\
\text { pathways 6.Improving teacher quality } \\
\text { knwoledge and progress 7a.Computer- } \\
\text { based learning and trest. 7b.Strengthening } \\
\text { IT knowledge in the } 4.0 \text { technology era }\end{array}$ \\
\hline & & $\begin{array}{l}\text { 1.1.2. Provide } \\
\text { self } \\
\text { development } \\
\text { services } \\
\text { towards get } \\
\text { best quality } \\
\text { competencies }\end{array}$ & $\begin{array}{l}\text { 1. Improving the quality of literacy } \\
\text { activities in schools. 2. Increasing } \\
\text { extracurricular activities at school by } \\
\text { adding several new extracurricular } \\
\text { activities such as Englishclub, } \\
\text { Marchingband, Youth Scientific Group } \\
\text { (KIR). 3. Involving students in various } \\
\text { competitions, both science and non- } \\
\text { science. 4. Improved maintenance of the } \\
\text { Natural Sciences (IPA) and Information } \\
\text { and Computer Engineering (ICT) labs. } 5 \text {. } \\
\text { Adding Wifi Installation Network. } 6 \text {. }\end{array}$ & $\begin{array}{l}\text { 1.Produce students' literacy works in the } \\
\text { form of synopsis, short stories or short } \\
\text { movies 2.Increasing international standard } \\
\text { non-academic achievements, as well as } \\
\text { strengthening character education } \\
\text { 3.Increased student achievement in science } \\
\text { and non-science competitions 4.Creating } \\
\text { comfort in science laboratories, libraries } \\
\text { and other learning facilities 5.Smooth wi-fi } \\
\text { traffic in the school's environment, so that } \\
\text { the learning program runs well and is fun } \\
\text { 6.Empowerment of Information } \\
\text { Technology }\end{array}$ \\
\hline
\end{tabular}

This publication is licensed under Creative Commons Attribution CC BY. 


\begin{tabular}{|c|c|c|}
\hline & $\begin{array}{l}\text { Provision of additional computers in the } \\
\text { library. } 7 \text {. Procurement of art exhibition } \\
\text { rooms made by students and Organizing } \\
\text { scheduled exhibitions of students' literacy } \\
\text { and artworks. } 8 \text {. Intensify academic and } \\
\text { non-academic supervision. } 9 \text {. Doing the } \\
\text { TOEFL test. 10. Giving the opportunity for } \\
\text { teachers to take comparative studies to } \\
\text { other schools. } 11 . \text { Involving students in } \\
\text { youth activities at the national level }\end{array}$ & $\begin{array}{l}\text { and Computer-based Tests } 7 \mathrm{a} . \text { Increased } \\
\text { creativity in the fields of culture and art } 7 \mathrm{~b} \text {. } \\
\text { Growing and improving the talents and } \\
\text { potential 8.To ensure and guarantee that } \\
\text { student output and outcomes are achieved } \\
\text { 9. Increasing the ability of students to } \\
\text { speak English in preparation for taking the } \\
\text { TOEFL. 10.Share experiences for friends to } \\
\text { see the International world 11.To ensure } \\
\text { and guarantee, to achieve the national } \\
\text { integrity of students }\end{array}$ \\
\hline $\begin{array}{l}\text { 1.1.3. } \\
\text { Organizing a } \\
\text { participatory, } \\
\text { active, creative, } \\
\text { effective, } \\
\text { innovative, } \\
\text { productive and } \\
\text { challenging } \\
\text { learning } \\
\text { process. }\end{array}$ & $\begin{array}{l}\text { 1. Improving the competence of } \\
\text { teachers/employees towards professional } \\
\text { staff; • Streamline academic supervision } \\
\text { activities • Involving teachers in } \\
\text { Information Technology (IT) training } \\
\text { Involving teachers in technical guidance } \\
\text { activities for Graduate Competency } \\
\text { Standards (SKL), National Examinations } \\
\text { and School Examinations (US) • Involving } \\
\text { teachers in teaching materials workshops. } \\
\text { 2. Improved readiness and motivation of } \\
\text { related components to obtain the best } \\
\text { learning outcomes (details in file) }\end{array}$ & $\begin{array}{l}\text { 1. Increasing the ability of teachers in } \\
\text { active, innovative, creative, and } \\
\text { participatory learning: • Increased } \\
\text { competence of teachers in making and } \\
\text { analyzing school exam questions } \bullet \\
\text { Increasing teacher competence through the } \\
\text { use of IT in classroom learning. • Increased } \\
\text { achievement and the growth of the spirit of } \\
\text { learning and the attitude of responsibility } \\
\text { of students. } \bullet \text { Improved performance and } \\
\text { discipline of employees/teachers. • Ensure } \\
\text { that teaching materials are understood } \\
\text { 2.Ensure increased motivation and } \\
\text { enthusiasm for learning in order to achieve } \\
\text { maximum and quality results }\end{array}$ \\
\hline $\begin{array}{l}\text { 1.1.4. Provide } \\
\text { continuous } \\
\text { quality services } \\
\text { for students } \\
\text { who have: } \\
\text { "Special } \\
\text { Intelligence and } \\
\text { Special Talent } \\
\text { (CIBI) }\end{array}$ & $\begin{array}{l}\text { 1. The deepening of the material for the } \\
\text { preparation of the science competition by } \\
\text { the Subject Teacher Consultative Forum } \\
\text { (MGMP) 2. Involving students who have } \\
\text { CIBI in the selection of Pre-Olympic } \\
\text { Science District Level pre OSK, OSK, OSP, } \\
\text { Pre OSN, OSN, and science competitions 3. } \\
\text { Involving students in the National Student } \\
\text { Sports Olympiad (O2SN) and the National } \\
\text { Student Art Competition Festival (FLS2N- } \\
\text { for students who have talents in sports } \\
\text { and arts) 4. Development of scientific } \\
\text { writing. 5. Organizing special classes } \\
\text { outside of teaching and learning activities } \\
\text { (KBM) for CIBI students in preparation for } \\
\text { science competitions. }\end{array}$ & $\begin{array}{l}\text { - Develop a spirit of competition and } \\
\text { achievement both at national and } \\
\text { international levels } \bullet \text { Increased transfer of } \\
\text { medals and awards in every science and } \\
\text { non-science event } \\
\end{array}$ \\
\hline
\end{tabular}




\begin{tabular}{|c|c|c|c|c|}
\hline 2 & $\begin{array}{l}\text { 2.Student (as } \\
\text { Mus lim) and } \\
\text { Development }\end{array}$ & $\begin{array}{l}\text { 2.1.As Muslim } \\
\text { Increase Faith } \\
\text { and Faith in } \\
\text { God Almighty }\end{array}$ & \begin{tabular}{|l|} 
1. Zuhr congreg ational prayer 2 . Doing \\
Muhadharah 3 . Commemoration of \\
religious holidays 4 . Tadarus every day \\
before learning activities beg in, 5 . Tadarus \\
together in the field every Friday, and in \\
the mosque followed by the Duha pray er 6. \\
Ramadan Islamic Boarding School for \\
Students
\end{tabular} & $\begin{array}{l}\text { The realization of ukuwah Islamiyah, as an } \\
\text { obligation to form a Muslim's respons ibility }\end{array}$ \\
\hline & & \begin{tabular}{|l|}
2.2. Develop \\
res earch \\
capability, \& \\
g lobal access \\
and technology \\
based network. \\
\end{tabular} & $\begin{array}{l}\text { 1.Improve the spirit of excellence for } \\
\text { students both nationally and } \\
\text { in ternationally, especially in the field of } \\
\text { res earch. } 2 \text {. Increas ing research activities } \\
\text { of class XI students other than OSN } \\
\text { participants. 3. Assistance with OSN }\end{array}$ & $\begin{array}{l}\text { 1.Increas ed achievement and enthusiasm } \\
\text { for research ing students } 2 \text {.Improving } \\
\text { student ach ievement through national and } \\
\text { international level competencies. }\end{array}$ \\
\hline \multirow[t]{2}{*}{3} & $\begin{array}{l}\text { 3.Public } \\
\text { relations }\end{array}$ & $\begin{array}{l}\text { 3.1.Creating an } \\
\text { orderly, safe, } \\
\text { clean, healthy, } \\
\text { beautifu } 1 \text { and } \\
\text { familial school } \\
\text { climate and } \\
\text { environment. }\end{array}$ & $\begin{array}{l}\text { 1. Improving the quality of in terpers onal } \\
\text { relationships among school; } \bullet \text { Outbound } \\
\text { activities } \bullet \text { Childbirth, illness and death and } \\
\text { Wedding visits } 2 \text {. Exercise tog ether } \\
\text { Collaborate with students in class meetings } \\
\text { and celebrations for national holidays }\end{array}$ & $\begin{array}{l}\text { Creat ing as a school big family's } \\
\text { atmosphere in the school environment, } \\
\text { love school, love family and to strengthen } \\
\text { nation integraty }\end{array}$ \\
\hline & & $\begin{array}{l}\text { 3.2. Create good } \\
\text { cooperation } \\
\text { with } \\
\text { steakholders }\end{array}$ & \begin{tabular}{|l|} 
1. Improving the quality relation; Improve \\
of relations with related \\
committees/institutions/stakeholders. \\
Completion of Committee manag ement \\
Committee meet ings $\cdot$ 2.Improving of \\
education on learning proses situation \\
(PBM) for clas sin the context of delivering \\
program activities $\cdot$ The importance of \\
education related to educational \\
exhibitions, entrepren eurship creation \\
festivals, and other celebrations. \\
Attending Mass Events 3. Establish \\
relationships with universities, other \\
educational institutions and psycholog ical \\
institutions $\cdot$ Carry out school \\
deliberations as great event for
\end{tabular} & $\begin{array}{l}\text { The establishment of good cooperation } \\
\text { with the committee, parents of students, } \\
\text { the surrounding commun ity, univers it ies, } \\
\text { Industrial Institution (DUDI), and related } \\
\text { in stitutions in order to improve the quality } \\
\text { of education. }\end{array}$ \\
\hline 4 & $\begin{array}{l}\text { 4.Facilities and } \\
\text { in frastructure }\end{array}$ & $\begin{array}{l}\text { 4.A pleas ant } \\
\text { school climate } \\
\text { and } \\
\text { environment }\end{array}$ & $\begin{array}{l}\text { 1.Equ ip school facilities to ach ieve a } \\
\text { conducive environment } 2 . \text { Repair and } \\
\text { Improve maintenance of school facilities } \\
\text { and in frastructure. } 3 . \text { School garden repair }\end{array}$ & $\begin{array}{l}\text { Create a beautiful and conducive } \\
\text { atmosphere in the school environment. }\end{array}$ \\
\hline \multirow[t]{4}{*}{5} & $\begin{array}{l}\text {.Org an ization } \\
\text { and } \\
\text { Man ag ement }\end{array}$ & $\begin{array}{l}\text { 5.1.School- } \\
\text { Based } \\
\text { Management } \\
(\text { SBM }) \text { and IT- } \\
\end{array}$ & $\begin{array}{l}\text { 1. Application of K13 and along side with } \\
\text { KTSP } 2 \text {. A } 11 \text { activities at school are } \\
\text { included in the school website } 3 \text {. Open } \\
\text { Management }\end{array}$ & $\begin{array}{l}\cdot \text { Increas ed leam ing programs and can run } \\
\text { well } \bullet \text { Improve a climate of openness and } \\
\text { tog etherness }\end{array}$ \\
\hline & & $\begin{array}{l}\text { 5.2. Become a } \\
\text { reference for } \\
\text { Banten } \\
\text { education units }\end{array}$ & $\begin{array}{l}\text { 1.Develop SMA-M } 25 \text { as a school with } \\
\text { excellent achievements both in academic } \\
\text { and non-academic terms } 2 \text {. The "Sister } \\
\text { School" program for having relation with } \\
\text { schools from abroad. } 3 \text {. Be the host for } \\
\text { every Inter-s chool Education Service }\end{array}$ & $\begin{array}{l}\text { - Making SMA M } 25 \text { a school with various } \\
\text { academic and non-academic achievements } \\
\text { - Promotion and information about SMA M } \\
25 \text { via Video Profile at web }\end{array}$ \\
\hline & & $\begin{array}{l}\text { 5.3. School with } \\
\text { orderly } \\
\text { admin is trat ion }\end{array}$ & $\begin{array}{l}\text { 1. Improving the files of teachers, } \\
\text { employees, and students in an effort to } \\
\text { improve school administration. }\end{array}$ & Org an ized school admin is tration \\
\hline & & $\begin{array}{l}\text { 5.4.Supervision, } \\
\text { Coaching and } \\
\text { Evaluation }\end{array}$ & $\begin{array}{l}\text { 1. Conduct class supervision } 2 \text {. Evaluating } \\
\text { reports on the implementation of teacher } \\
\text { duties such as daily test scores, general } \\
\text { tests and other reports } 3 \text {. Hold regular } \\
\text { activity evaluation meetings } 4 \text {. Daily } \\
\text { meeting ( } 10 \text { minutes before the bell) for } \\
\text { motivation and innovation }\end{array}$ & $\begin{array}{l}\text { A ccuracy and clarity of achieving school } \\
\text { goals according to schedule }\end{array}$ \\
\hline
\end{tabular}

This publication is licensed under Creative Commons Attribution CC BY. 


\section{Matrix of 4.1.2. Medium-Long term program for academic year 2020/2021 to 2025/2026, For 5 years}

\begin{tabular}{|c|c|c|}
\hline No. & PROGRAM TYPE & PROGRAM DESCRIPTION \\
\hline 1 & $\begin{array}{l}\text { Strengthening Curriculum } \\
\text { Documents (Implementation and } \\
\text { development) }\end{array}$ & $\begin{array}{l}- \text { Develop Curriculum-13 (K-13), by combining National Curriculum and Olympics } \bullet \text { Mapping SKL, } \\
\text { Core Competencies }(\mathrm{KI}) \text {, and Basic Competencies }(\mathrm{KD}) \text { into Packages or couse pack and } \bullet \text { Create } \\
\text { academic and non-academic guidelines }\end{array}$ \\
\hline 2 & $\begin{array}{l}\text { Planning, Implementation, and } \\
\text { Evaluation of Leaming }\end{array}$ & $\begin{array}{l}\cdot \text { Develop face-to-face subject designs, structured assignments, independent as signments } \\
\text { Compile the subjects of syllabus } \bullet \text { Develop a Leaming Implementation Plan } \bullet \text { Prepare a variety of } \\
\text { teaching materials } \bullet \text { Develop A ssessment Tools } \bullet \text { Carry out leaming and as sessment processes, } \\
\text { academic and non-academic as sistance, use of libraries and laboratories, enrichment and remedial } \\
\text { activities } \bullet \text { Monitor planning, implementation, and as ses sment twice every month }\end{array}$ \\
\hline 3 & $\begin{array}{l}\text { Improving the Quality of } \\
\text { Educators and Education } \\
\text { Pers onnel }\end{array}$ & $\begin{array}{l}\text { - } 95 \% \text { of educators obtain professional certificates } \cdot 95 \% \text { of educators have improved their skills } \\
\text { in the development of various teaching materials (ICT-bas ed) } \cdot 95 \% \text { of education staff acquire } \\
\text { expertise in accordance with their duties (such as computer technicians, laboratory ass is tants, } \\
\text { librarians, etc.) }\end{array}$ \\
\hline 4 & $\begin{array}{l}\text { Increas ing the quantity and } \\
\text { quality of Educational Facilities } \\
\text { and Infrastmecture }\end{array}$ & $\begin{array}{l}\text { - } 95 \% \text { of clas srooms are equipped with complete ICT tools perangkat } \bullet \text { Fix and improve library } \\
\text { materials and library facilities } \bullet \text { Designing a multimedia laboratory } \bullet \text { Rehabilitate the old building }\end{array}$ \\
\hline 5 & $\begin{array}{l}\text { Improving ICT-Based } \\
\text { Management In formation } \\
\text { System }\end{array}$ & $\begin{array}{l}- \text { Develop a School Information System (SIM) for SMA-M25, especially in the academic field in } \\
\text { the new school year and beyond }\end{array}$ \\
\hline 6 & $\begin{array}{l}\text { Rais ing and strengthening the } \\
\text { role of wider stakeholders }\end{array}$ & $\begin{array}{l}\text { - Optimizing donors and spons ors to meet school financing needs independently } \bullet \text { Optimizing } \\
\text { partnership programs and sister schools, especially with domestic schools } \bullet \text { Optimizing the role of } \\
\text { school committees in the context of developing school quality } \bullet \text { Explore potential alumni }\end{array}$ \\
\hline
\end{tabular}

\section{Matrix of 4.1.3. Quality Improvement Program in SMA M 255 Banten}

\begin{tabular}{|c|c|c|}
\hline No. & EXPECTED COMPETENCIES & IMPLEMENTA TION STRA TEGY \\
\hline 1 & $\begin{array}{l}\text { Application of } 8 \mathrm{SNP} \text { stan dards } \\
\text { and application of quality } \\
\text { awarenes }\end{array}$ & $\begin{array}{l}\text { A.Monitoring and Internal Au dit implementation of } 8 \mathrm{SNP} \text { standards. B.Implementation of the } \\
\text { awarenes of Quality Culture of Education; } 1 \text {. Significance, i.e. the plans prepared must make a } \\
\text { significant contribution to the ach ievement of the quality of gradu ates } 2 \text {. Flexibility, ie all } \\
\text { edu cational activities to be carried out must be easy to implement, } 3 \text {. Relevance, namely planning } \\
\text { always focu ses on efforts to present appropriate procedures for achieving educational goals . } \\
\text { 4.Definitiveness, wh ich is able to provide assurance that the data used will be able to predict the } \\
\text { achievement of the quality of graduates } 5 . \text { Adaptability, meaning planning as someth ing dynamic } \\
\text { 6.Time bond, meaning adherence to the period (periodization) 7.Monitoring, meaning education } \\
\text { planning through in dicators that have been set } 8 \text {. Subject Matter, namely the content or material } \\
\text { of the plan that will be implemented in the future.) }\end{array}$ \\
\hline 2 & $\begin{array}{l}\text { Mastery of knowledge taught by } \\
\text { the teacher }\end{array}$ & $\begin{array}{l}\text { 1. Provide opportun ities for teachers to continue their studies (Post-graduate) 2. Following Similar } \\
\text { MGMP 3. Participate in seminars, workshops, training outside of school. 4. Organizing IHT } \\
\text { Utilization of the Internet and Smart Applications for learning and assessment. 5. Textbooks. } 6 \text {. } \\
\text { Supporting Book. 7. Leaming CD }\end{array}$ \\
\hline 3 & $\begin{array}{l}\text { Teachers become In spiring } \\
\text { students }\end{array}$ & $\begin{array}{l}\text { Throu gh various exercises, students become creative with great ideas, to achieve international } \\
\text { level knowledge }\end{array}$ \\
\hline 4 & $\begin{array}{l}\text { All students of class XII must } \\
\text { pass the School Exam }\end{array}$ & $\begin{array}{l}\text { The process of streng thening in the form of continu ous practice questions with reference to the } \\
\text { SKL, with a scheduled time, in order to achieve quality graduates and high outcomes }\end{array}$ \\
\hline 5 & $\begin{array}{l}\text { Increased outcome/percentage } \\
\text { accepted at PTN through test } \\
\text { and non-test routes to more than } \\
80 \%\end{array}$ & $\begin{array}{l}\text { Materials deepening program and learning clinic; - Try Out, } 5 \text { times from school and } 2 \text { times from } \\
\text { other ag encies, as well as. Training motivation }\end{array}$ \\
\hline 6 & $\begin{array}{l}\text { Students in class X and XI are } \\
\text { tried / must go up to class XII } \\
\text { with high output }\end{array}$ & $\begin{array}{l}\text { Continuous material reinforcement materi. } \cdot \text { Performing various tests and analyzing the results. } \bullet \\
\text { Con ducting clinical learning. } \bullet \text { mplement remedial and enrichment prog rams } \bullet \text { Organizing learning } \\
\text { about OSN (scheduled) }\end{array}$ \\
\hline
\end{tabular}

\section{Development of Hizbul Wathan (HW)}

Hizbul Wathan activities are compulsory extracurricular activities for Muhammadiyah high school students. The Hizbul Wathan Scout Movement is part of a forum tasked with training the younger generation through an intelligence system that breathes Islam and this movement has many similarities to Scouts, and this movement is Islamic, based on the Koran and Sunnah, its founder Mr. K.H. 
Ahmad Dahlan is a scientist, preacher, and educator. with a broad view. The development of students is always enthusiastic, both in participating in formal and non-formal activities which are considered very developed.

The implementation of HW activities is mandatory in Muhammadiyah schools, it has been proven to be able to direct latent abilities for students, and can give birth to character values in order to create good students. HW's activities at SMA M25, Hizbul Wathan's scouting activities, are a manifestation of the behavior expected by the nation; spirit, high integrity and sincerity and seek Allah SWT, while maintaining and preserving the teachings of discipline in Islam. The achievement of Hizbul Wathan (HW) goals is achieved through the following efforts: 1. Amar ma'ruf nahi munkar (encourage good behavior and prevent) educates young men and women who like to do charity and compete in virtue. 2. Build character and personality in accordance with Islamic teachings. 3. Realizing the young generation of sons and daughters to become Muslims who have noble character, are virtuous, physically and mentally healthy. 4.Improvement and promotion of education and teaching, culture and expansion of knowledge in accordance with Islamic teachings. 5. Become a cadre of management in the Muhammadiyah organization. HW is to raise children, youth and youth, namely: 1. Having faith, and being physically and mentally strong, 2 . Knowledgeable and technological and of good character.

It is clear that to achieve success in this regard, the quality of education is not enough only with academic achievement, but must be comprehensively accompanied by non-academic achievements, one of which is HW scouting education. The point is that young people can enforce discipline with smar ma'ruf nahi munkar, compete healthily, have noble character and are responsible and can realize their ideals, and the aspirations of parents, nation and state, this is the way to quality education.

\section{Quality of Education}

To find out the success in achieving the quality of education, an evaluation is carried out through the Internal Quality Audit program which is carried out by the Quality Assurance Agency as an internal quality assurance institution. Internal Quality Audit (AMI) is an activity to evaluate the achievement of quality standards by every organ in SMA M25 Bnten, carried out every year. Likewise, apart from AMI, there is also a monev from the education office to provide input on the shortcomings that occur. In the end, the government through the education office/National Accreditation Board conducted accreditation, which resulted in SMS M25, Banten being awarded level A. In addition, there were other successes, including: 1 The value of its output continues to increase. 2. Outcomes also continue to be successful in being able to continue to the next level of education, and 3. Student enrollment also continues to increase and 4. Support or support from parents and members of Muhammadiyah Organization is generally very optimistic to advance the school

\section{CONCLUSION}

SMA M25, Banten in implementing education management has a vision and mission formulation that is based on Islamic values. So that all activity programs in the university environment are required to integrate Islamic values as an important element in Islamic education and as a foundation in giving birth to an ideal national leader. In the aspect of Islamic education. SMA M25 Banten has implemented strategic management which includes; Strategic formulation, strategic implementation and strategic evaluation, so that all activities can be measured which are periodically evaluated in the context of control and control, so that the quality of education can continue to be improved

The role of the leader in relation to the implementation of the work program contained in Strategic Management, must be carried out seriously, obediently, obeying the rules and schedules that have been set, because this can affect the success of an Islamic Education Institution in improving the quality of education. Therefore, it takes the characteristics of an ideal leader who is able to emulate the leadership of the Prophet who has the characteristics of fathonah, sidiq, amanah and tabligh. This ideal leadership has an influence on Islamic educational institutions in giving birth to a quality culture

Strengthening character education through Hizbul Wathan in their respective schools so that students always understand clearly, in addition to the material provided by the coach, students can implement it in the wider community that reflects the competence of students. Every learner instinctively protects, defends, and defends what he has from the interference of strangers. The Hizbul Wathan (HW) Scouting Movement invites all elements of the nation to unite, establish Ukhuwah Islamiyah (islamic brotherhood) and Wathaniyah (compatriots), as well as mutual cooperation and respect for each other and commitment. With full awareness, the direction and goals of the quality of education will be achieved.

\section{REFERENCES}

[1] Aldo Redho Syam, (December 2017; Konsep Kepemimpinan Bermutu dalam Pendidikan Islam (The Concept of Quality Leadership in Islamic Education), Jurnal At-Ta'dib. Vol. 12. No. 2,

[2] Budio, S. (2019). Stategi Manajemn Sekolah. Jurnal Menata, 56-72.

[3] Encarnacion Garza, Jr. at all, September 2014, Leadership for school success: Lessons from effective principals, Department of Educational Leadership \& Policy Studies, University of Texas at San Antonio San Antonio, TX 78209 United States of America

[4] Haryanto. 2019. Strategi Kepemimpinan Kepala Sekolah Dalam Meningkatkan Kualitas Kinerja Pendidik (Principal's Leadership Strategy in Improving the Quality of Educator Performance). Jurnal Palapa, Vo.7(2), 1-15.

[5] Holis, Gus. 2013. Kurikulum 2013 | KI-KD Untuk SD/MI dan SMP/ MTs. http://guraru.org/guru-berbagi/kurikulum- 2013-sk-kd-untuk-sdmi

[6] Irani. 2019. Implementasi Manajemen Strategik. Jurnal Administrasi Pendidikan, Vol. 4(2), 57-80.

This publication is licensed under Creative Commons Attribution CC BY.

http://dx.doi.org/10.29322/IJSRP.11.08.2021.p11634

WWw.ijsrp.org 
[7] John Nikolaros, April 2015 ;Strategies for Effective School Leadership, Global Journal of Educational Studies ISSN 2377-3936 2015, Vol. 1, No. 1

[8] Qomar. 2017. Manajemen Pendidikan Islam. Jurnal Manajemen Pendidikan, Vol. 2(1), 1-14.

[9] Riyanto, Fajar (2016), Keterampilan Kepemimpinan Kepala Sekolah dan Strategi Dalam Peningkatan Mutu Sekolah (Studi Kasus SDIT An Nisa Kedawung. Surakrta: program Pasca Sarjana Universitas Muhamadiyah Surakarta).

[10] Rosi Rosita,-2016, Usaha Kepala Sekolah dalam Meningkatkan Mutu Pendidikan Islam. Junal TARBAWY, Vol. 3, Nomor 1

[11] Sa'adah Erliani, Oktober, 2016, Peranan Gerakan Pramuka untuk membentuk Karakter Kepedulian Sosial dan Kemandirian (Studi Kasus di SDIT Ukhwah dan MIS An- Nuriyyah 2 Banjarmasin), Jurnal; Mualiimuna Vol. 2, No 1, smpmts/ (21 November 2014)

[12] Thaib, M. I. (2018). Kepemimpinan Pendidikan dalam Islam. Jurnal Intelektualita, 66-95.

[13] Tim Penulis AIK, 2018, Kemuhammadiyahan, Jakarta: Uhamka Press.

[14] Umar, Mardan \& Ismail, Feiby, 2017, Peningkatan Mutu Lembaga Pendidikan Islam, (Tinjauan Konsep Mutu Edward Deming dan Joseph Juran), Jurnal Pendidikan Islam Iqra', Vol. 11 Nomor 2, Fakultas Tarbiyah dan Ilmu Keguruan [FTIK], IAIN Manado

[15] Undang-Undang RI ,2016,Nomor 20 Tahun 2003 Tentang SISDIKNAS \& Peraturan Pemerintah RI Tahun 2015, Bandung:

[16] Yudiatmaja. 2018. Kepemimpinan dan Konsep Karakternya. Jurnal Medkom, Vol.12(2),29-38.

\section{AUTHORS}

First Author - Margono Mitrohardjono, Dosen Program Doktor, MPI, Universitas Muhamadiyah Jakarta Email: margono.mitrohardjono@gmail.com

Second Author -Sularno, Program Doktor S3, MPI, Universitas Muhammadiyah, Jakarta Email: larno63@yahoo.co.id 